\title{
Isolation and biochemical characterization of acid tolerance xylanase producing Bacteria, Bacillus sp. GJY from city park soil
}

\author{
Min-Young Jang ${ }^{1} \cdot$ Hwa Rang Park ${ }^{1} \cdot$ Chong Gyu Lee $^{1} \cdot$ Gab-Chul Choo $^{1} \cdot$ \\ Hyun Seo Cho ${ }^{1} \cdot$ Sam-Bong Park ${ }^{1} \cdot$ Ki-Cheol $\mathrm{Oh}^{2} \cdot$ Bong-Gyu Kim $^{1}$ (1)

\section{도심공원으로부터 산내성 xylanase를 생산하는 박테리아 분리 및 효소학적 특성}

\author{
장민영 ${ }^{1} \cdot$ 박화랑 $^{1} \cdot$ 이총규 $^{1}$ 추갑철 ${ }^{1}$ 조현서 ${ }^{1} \cdot$ 박삼봉 $^{1} \cdot$ 오기철 $^{2} \cdot$ 김봉규 $^{1}$
}

Received: 23 January 2017 / Accepted: 25 January 2017 / Published Online: 31 March 2017

(C) The Korean Society for Applied Biological Chemistry 2017

\begin{abstract}
Microbes in forest are very important due to not only to enhance soil fertility but also maintain a healthy ecosystem by supplying the energy available to living organisms by producing various kinds of enzymes related to degradation of lignocellulosic biomass. In order to isolate a lignocellulosic biomass degrading bacterial strain from the Jurassic park located in Gyeongnam National University of Science and Technology, We used the Luria-Bertani-Carboxymethyl cellulose (CMC) agar trypan blue method containing $0.4 \%$ carboxymethyl cellulose and $0.01 \%$ trypan blue. As a result, we isolated a bacterial strain showing both activity on the CMC and xylan. To identify the isolated strain, 16S rRNA sequencing and API kit analysis were used. The isolated strain turned out to belong to Bacillus species and then named Bacillus sp. GJY. In the CMC zymogram analysis, it showed that one active band of about $28 \mathrm{kDa}$ in size is present. Xylan zymogram analysis also showed to have one active band of
\end{abstract}

Kim Bong-Gyu $(\triangle)$

E-mail:dkimbk@gntech.ac.kr

${ }^{1}$ Department of Forest Resources, Gyeongnam National University of Science and Technology, 33 Dongjin-ro, Jinju-si, Gyeongnam, Jinju 52725, Republic of Korea

${ }^{2}$ Nakdong River Basin Environmental Office, Changwon 51439, Republic of Korea

This is an Open Access article distributed under the terms of the Creative Commons Attribution Non-Commercial License (http://creativecommons. org/licenses/by-nc/3.0/) which permits unrestricted non-commercial use, distribution, and reproduction in any medium, provided the original work is properly cited. about $25 \mathrm{kDa}$ in size. The optimal growth temperature of Bacillus sp. GJY was $37^{\circ} \mathrm{C}$. The maximal activities of CMCase and xylanase were 12 hour after incubation. The optimal $\mathrm{pH}$ and temperature for CMCase were 5.0 and $40{ }^{\circ} \mathrm{C}$, respectively, whereas the optimal $\mathrm{pH}$ and temperature for xylanase was 4.0 and $40{ }^{\circ} \mathrm{C}$. Both activities for CMCase and xylanase showed to be thermally stable at 40 and $50^{\circ} \mathrm{C}$, while both activities rapidly decreased at over $60{ }^{\circ} \mathrm{C}$.

Keywords Bacillus sp. · Carboxymethyl cellulase · Lignocellulosic biomass $\cdot$ Xylanase

\section{서 론}

솦은 다양한 생물들이 서식하는 공간으로 복잡한 생태계를 이 루고 있다. 숲이 건전하게 유지되기 위해서는 산림생태계 내로 양질의 영양원이 지속적으로 공급 되어야 한다(Waldrop 등, 2004; Ayres 등, 2009; Yang 등, 2014). 숲에 유입되는 대부분 의 영양원은 광합성에 의하여 생성되는 낙엽, 낙지 또는 고사 한 식물과 같은 목질바이오매스이다(Potter과 Kloster 1997). 이 러한 유기물의 대부분은 $\beta-1,4$-glucan의 불용성 섬유로 이루어 진 셀룰로오스와 xylan, mannans, glucans을 포함하는 비셀룰로 오스 다당류인 헤미셀룰로오스가 리그닌과 강력한 복합체를 형 성하고 있다(Urbanová 등, 2015). 피자식물(angiosperm) 목질부 의 경우 $42-50 \%$ 의 셀룰로오스, $25-30 \%$ 의 헤미셀룰로오스, 20 $35 \%$ 의 리그닌과 약 $25-30 \%$ 의 수용액으로 이루어져 있다 
(Whistler과 Richards 1970; Kumar 등, 2008). 목질바이오매스 는 숲 토양의 특성과 비옥도 개량뿐만 아니라 숲 생태계의 균 형을 조절하기 위한 중요한 탄소원으로 제공된다(Potter과 Klooster 1997; Waldrop 등, 2004; Ayres 등, 2009). 목질바이 오매스가 숲 생태계를 이루고 있는 생물의 영양원으로 이용되 기 위해서는 다당류형태의 목질바이오매스가 단당류로 형태로 전환이 되어야 한다. 다양한 종류의 미생물에 의해 체외로 분 비되는 폴리페놀 산화효소, cellulase, xylanase, $\beta$-glucosidase와 같은 다양한 종류의 탄수화물 분해효소 등에 의해서 목질바이 오매스는 D-glucose, D-galactose, D-mannose, L-arabinose, Dribose, D-xylose와 같은 단당류와 페놀릭 화합물로 가수분해 된 다(Kumar 등, 2008; Urbanová 등, 2015).

그람 양성균인 Clostridium속, Cellulomonas속, Thermomonospora 속과 진균류인 Trichderma속, Aspergillus속이 생산하는 탄수화 물 분해효소들은 오늘날 펄프산업, 식품산업, 동물사료가공 등 과 관련된 분야에 이용된다(Kuhad 등, 1999; $\mathrm{Min}$ 등, 2002; Sun과 Cheong, 2002; Sukumaran 등, 2005; Kuhad 등, 2011). 최근 들어 DNA분석방법의 발달을 통하여 많은 종류의 목질바 이오매스 분해 미생물들에 대한 연구가 많이 진행되고 있다. 산 림토양을 대상으로 $16 \mathrm{~S} \mathrm{rRNA}$ 유전자 염기서열분석법으로 종 을 동정한 결과 Bacillus속과 Paenibacillus속에 관련된 균주가 많은 부분을 차지하고 있었다(Wilson 2011; Yang 등, 2014). 특히 Bacillus속 균주는 산림토양에 유입되는 유기물의 분해에 관여 하여 숲의 건강한 생태환경 유지에 큰 역할을 담당할 뿐 만 아니라 탄소순환에 있어 매우 중요한 부분을 담당하고 있다 (Demain 등, 2005; Yang 등, 2014).

산림에 서식하는 대부분의 생명체들은 다양한 종류의 목재 부후균 및 미생물의 상호작용에 의해 목질바이오매스로부터 공 급되는 영양분으로 살아간다. 목질바이오매스 분해에 중요한 역 하는 하는 미생물들은 또한 종이산업, 식품 산업, 바이오에탄올 생산 등과 같은 각종 산업에 이용 가능하기 때문에 숲은 우수 한 섬유소 분해 미생물을 얻기 위한 좋은 자원 중의 하나이다. 특히, Bacillus 종은 다양한 종류의 목질바이오매스 분해 효소 들을 생산하고 곰팡이나 효모에 비해서 생장속도가 굉장히 빠 르고, 배양이 쉽고, 유전자 조작이 가능하기 때문에 산업적으로 많이 사용된다(Tjalsma 등, 2004; Khandeparker 등, 2011; Zang과 Zhang 2011). 현재 상업적으로 사용되고 있는 섬유소 분해 효소의 약 $50 \%$ 이상은 Bacillus 종으로부터 기원한다 (Schallmey 등, 2004).

본 연구에서 산림토양으로부터 산 내성 xylanase 박테리아 Bacillus sp. GJY를 분리 - 동정 하고, Bacillus sp. GJY가 생산 하는 CMCase와 xylanase의 활성에 영향을 미치는 특성들을 구 명하였다.

\section{재료 및 방법}

\section{목질바이오매스 분해 토양 박테리아 분리}

목질바이오매스 분해 토양 박테리아 분리를 위해 경남과학기 술대학교내의 약 60-80년생의 활엽수와 침엽수가 약 $8: 2$ 의 비 율로 이루어진 쥬라기 숲에서 2015년 3월에 토양샘플을 채집하 였다. 각기 다른 세 군데의 장소에서 소독한 원예용 모종삽을
이용하여 지표면으로부터 $10 \mathrm{~cm}$ 아래 부분에서 약 $100 \mathrm{~g}$ 의 토 양샘플을 채취하였다. 토양은 실험실로 운반한 후 가는체(2-mm) 를 사용하여 큰 부유물을 제거하고 남은 부드러운 토양을 실험 에 이용하였다. 토양 $1 \mathrm{~g}$ 을 멸균수 $9 \mathrm{~mL}$ 에 첨가하여 소용돌이 교반기를 이용하여 잘 섞어 주었다. 그 후 샘플은 $10^{-1}, 10^{-2}$, $10^{-3}, 10^{-4}, 10^{-5}, 10^{-6}$ 배로 희석하여 10 분간 정치 배양 후 실 험에 이용하였다. 각 비율로 희석된 샘플은 $0.01 \%$ trypan blue (Sigma-Aldrich, St, Louis, MO, USA)와 $0.4 \%$ carboxymethyl cellulose $(\mathrm{CMC})$ 가 첨가된 Luria-Bertani (LB) agar plate에 $100 \mu \mathrm{L}$ 씩 도말 하여 $30{ }^{\circ} \mathrm{C}$ 인큐베이터에서 2 일간 배양하였다. 목질바이오매스 분해 박테리아는 균락의 주변에 생기는 밝은 색 의 halo의 존재 유무에 근거 하여 선발하였다. 선발된 균주의 액체 배양은 $\mathrm{LB}$ 배지를 이용하여 $30^{\circ} \mathrm{C}, 200 \mathrm{rpm}$ 의 조건에서 24 시간 진탕 배양하였다. 배양액은 $4{ }^{\circ} \mathrm{C}, 3,500 \mathrm{rpm}$ 의 환경에서 10 분간 원심 분리하여 조효소 액이 들어 있는 상등액을 회수 하였으며, CMCase 및 xylanase의 활성 검정에 이용하였다.

\section{$16 S$ rRNA 유전자를 이용한 박테리아 동정}

도시공원 토양으로부터 분리한 목질바이오매스 분해 박테리아 균의 동정을 위해 사용된 $16 \mathrm{~S}$ rRNA universal primer는 Forward primer로서 877F: 5'-CGGAGAGTTTGATCCTGG-3' 와 Reverse primer로서 878R: 5'-TACGGCTACCTTGTTAGCG $\mathrm{AC}-3^{\prime}$ 이었다. $16 \mathrm{~S}$ rRNA 유전자는 제조사의 사용설명서에 따라 Qiagen DNeasy kit (Hilden, Germany)를 사용하여 분리한 게 놈 $\mathrm{DNA}$ 를 이용하여 polymerase chain reaction (PCR)을 이용 하여 증폭하였다. $\mathrm{PCR}$ 반응용액은 게놈 $\mathrm{DNA}$ 의 $1 \mu \mathrm{L}, 2.5 \mathrm{mM}$ $\mathrm{dNTPs}$ 의 $3 \mu \mathrm{L}, 10 \mathrm{X}$ 반응 완충용액의 $3 \mu \mathrm{L}$, 각각의 primer $(10 \mathrm{pmol} / \mathrm{uL}$ )의 $3 \mu \mathrm{L}$, nTaq-HOT polymerase (Enzynomics, Daejeon, Korea)의 $0.3 \mu \mathrm{L}$ 와 멸균수를 첨가하여 최종볼륨이 30 $\mu \mathrm{L}$ 가 되게 조제 하였다. PCR은 Taq-HOT polymerase를 활성 화시키기 위하여 $94{ }^{\circ} \mathrm{C} 10$ 분간 반응한 후 $94{ }^{\circ} \mathrm{C}$ 에서 30 초, $55^{\circ} \mathrm{C}$ 에서 1 분, $72{ }^{\circ} \mathrm{C}$ 에서 1 분 30 초의 사이클을 총 40 회 실시 한 후 $72{ }^{\circ} \mathrm{C}$ 에서 10 분간 반응을 실시하였다. $\mathrm{PCR}$ 반응물 $1.5 \%$ 아가로스 겔을 이용하여 전기영동을 실시하였다. 아가로스겔상 에서 예상되는 크기에 위치한 $\mathrm{DNA}$ 를 면도칼로 자른 후 DNA 정제 키트(Bioneer, Daejeon, Korea)를 이용하여 순수한 DNA를 정제하였다. 정제한 $16 \mathrm{~S}$ rRNA 유전자는 pGEMT-easy 벡터 (Promega, Madison, WI, USA)에 클로닝 하여 염기서열을 분석 하였다. $16 \mathrm{~S}$ rRNA유전자의 염기서열 유사성과 multiple sequence alignment는 National Center for Biotechnology Information (NCBI)에서 제공하는 BLSTN과 CLUSTAL W 프로그램을 이 용하여 분석하였다. 분리한 Bacillus 종의 $16 \mathrm{~S}$ rRNA유전자의 염기서열과 기존에 보고된 다른 박테리아의 $16 \mathrm{~S} \mathrm{rRNA}$ 유전자 염기서열을 이용하여 계통도를 작성하였다. 계통도는 Molecular Evolutionary Genetics Analysis 6.0 (MEGA 6.0) 프로그램에 내장되어 있는 neighbor-joining 방법을 이용하였다(Tamura 등, 2013). 1,000번의 반복에 의해 생성된 데이터를 이용한 Bootstrap 분석은 계통도의 신뢰도와 분지 패턴을 평가하기 위 하여 사용하였다.

\section{Zymogram 분석}

CMC-SDS-PAGE와 xylan-SDS-PAGE는 Lee 등(2016)에 의해 
기술된 방법을 따라 수행하였다. 단백질의 전기영동은 $0.4 \%$ $\mathrm{CMC}$ 또는 xylan을 포함하고 있는 $10 \% \mathrm{SDS}-\mathrm{PAGE}$ 를 이용하 여 실시하였다. 전개된 단백질의 refolding을 위하여, $1 \%(\mathrm{v} / \mathrm{v})$ Triton X-100이 첨가된 $10 \mathrm{mM}$ sodium acetate buffer ( $\mathrm{pH}$ $5.0)$ 의 $200 \mathrm{~mL}$ 를 첨가하여 45 shacking 인큐베이터에서 밤새도 록 배양하였다. 다음날 아침 $10 \mathrm{mM}$ sodium acetate buffer (pH 5.0)를 이용하여 $50{ }^{\circ} \mathrm{C}, 120 \mathrm{rpm}$ 이 유지되는 인큐베이터에 서 CMCase를 위해서는 8시간, xylanase를 위해서는 14시간 배 양 하였다. 그 후 상온에서 $0.5 \%(\mathrm{w} / \mathrm{v})$ Congo red 로 30 분간 SDS-PAGE gel을 염색하고, $1 \mathrm{M} \mathrm{NaCl}$ 을 이용하여 붉은 색의 배경을 가진 gel에서 옅은 붉은 색의 가수분해 zone이 나타날 때까지 탈색하였다. 최종적으로 선명한 결과 사진을 얻기 위하 여 $0.1 \mathrm{M} \mathrm{HCl}$ 을 gel의 배양액에 조금씩 첨가하여 배경색을 변 화시켜가며 가수분해 zone이 선명하게 나타날 때 사진을 촬영 하였다.

\section{효소활성 측정}

CMCase와 xylanase 활성은 환원당 정량에 널리 사용되는 $\mathrm{DNS}$ 법(Nelson, 1994)을 사용하였다. Bacillus sp. GJY 의 조효소액 을 이용하여 $\mathrm{CMCase}$ 또는 xylanase의 효소활성은 $50{ }^{\circ} \mathrm{C}$ 에서 30 분간 xylan 또는 $\mathrm{CMC}$ 를 기질로 첨가하여 배양하는 동안 생 성되는 환원당의 양을 측정하는 것에 의하여 결정하였다. 효소 의 1 unit는 분당 $1 \mu \mathrm{mol}$ 을 생성하는데 필요한 효소의 양으로 정의하였다. 반응액은 $50 \mathrm{mM}$ sodium acetate buffer $(\mathrm{pH} 5.0)$, $1 \%$ (w/v) xylan 또는 $\mathrm{CMC}$, 조효소액 0.5 unit가 되게 최종 볼륨을 $1 \mathrm{~mL}$ 로 준비하였다. 30 분간 반응 후 생성된 환원당은 동량의 $1 \%$ dinitrosalicyclic acid (DNS) 첨가한 후 $100{ }^{\circ} \mathrm{C}$ 에서 5 분간 긇여 반응물을 발색 시킨 후 분광광도계를 이용하여 $540 \mathrm{~nm}$ 에서 측정하였다. CMCase 또는 xylanase 의 적정반응온 도를 결정하기 위하여 각 각의 반응액은 $20,30,40,50,60$, $70{ }^{\circ} \mathrm{C}$ 의 온도에서 30 분간 반응하여 효소활성을 측정하였다. $\mathrm{CMCase}$ 또는 xylanase의 열 안정성은 각기 다른 온도(40, 50, $70{ }^{\circ} \mathrm{C}$ )에서 효소를 전 배양한 후 남아있는 효소 활성을 측정하 였다. CMCase 또는 xylanase의 적정 $\mathrm{pH}$ 를 결정하기 위하여 $\mathrm{pH}$ 3.0-6.0은 $50 \mathrm{mM}$ sodium acetate 버퍼, $\mathrm{pH}$ 7.0-8.0은 50 $\mathrm{mM}$ sodium phosphate 버퍼, $\mathrm{pH} 8.0-9.0$ 은 $50 \mathrm{mM}$ Tris- $\mathrm{HCl}$ 버퍼를 이용하여 측정하였다.

\section{결과 및 고찰}

\section{섬유소 분해 박테리아의 분리와 동정}

도심공원 토양으로부터 셀룰로오스 가수분해가 가능한 박테리 아를 분리하기 위해 LB-CMC trypan blue agar 선발 방법을 이용하였다. 도심공원으로부터 채취한 토양을 2-mm 직경 체를 이용하여 큰 부피의 토양을 제거한 후 멸균수에 10 배씩 희석하 여 LB-CMC trypan blue agar 배지 plate에 도말 하여 30도 배양기에서 배양하였다. 배양 48시간 후 균의 주변에 생기는 halo의 유무에 따라 섬유소 분해 균주를 구분하였다. 그 중에 상대적으로 넓은 범위의 halo를 보이는 약 50 여개의 박테리아 를 동일 배지에 계대배양 하였으며, 상대적으로 높은 활성을 보 이는 10 개의 박테리아를 순수 분리하였다. 10 개의 박테리아는
$2 \mathrm{~mL} \mathrm{LB}$ 액체 배지를 담고 있는 각각의 시험관 $(20 \times 150 \mathrm{~mm})$ 에 접종하여 $37^{\circ} \mathrm{C}$ 에서 밤샘 배양하였다. 다음 날 원심분리를 통하 여 상등 액을 회수하여 $\mathrm{CMC}$ 를 기질로 하여 반응한 후 $\mathrm{DNS}$ 방법으로 효소활성을 측정하였고 여기서 상대적으로 높은 활성 을 보이는 박테리아를 선발하여 다음 실험에 이용하였다.

API kit (bioMerieux. Vitek, Marcy l'Etoile, France)의 그람 양성 API $50 \mathrm{CH}$ kit를 이용하여 분리한 균주의 생화학적 특성 을 분석하였다(Table 1). 그 결과 본 균주는 $\beta$-xylosidase, leucine arylamidase, phenylalanine arylamidase, $\beta$-galactosidase, L-pyrrolydonyl-arylamidase, $\alpha$-galactosidase, alanine arylamidase, tyrosine arylamidase, $\beta$-glucosidase, $\beta$-mannosidase, $\alpha$-glucosidase, esculin hydrolyase 등과 같은 효소활성을 가지는 것으로 나타났 다. 또한 본 균주는 $6.5 \%$ 의 $\mathrm{NaCl}$ 용액에서 생장이 가능한 반 면, kanamycin과 oleandomycin에 대한 저항성은 없었다. 이상 의 생화학적 특성에 기초하여 분석한 결과 본 균주는 Bacillus subtililis/amyloquefaciens/atrophaeus 종일 가능성이 약 $98 \%$ 이 상이었다(Table 1). 이에 부가적으로 $16 \mathrm{~S}$ rRNA 유전자의 염기 서열을 이용하여 균을 동정하였다. 분리한 균주의 게놈 $\mathrm{DNA}$ 를 주형으로 하여 리보솜의 소단위체를 코딩하는 $16 \mathrm{~S} \mathrm{rRNA}$ 유전 자 부분을 PCR을 통하여 증폭하였으며, PCR 산물을 pGEMTeasy 벡터(promega)에 클로닝 하여 염기서열을 분석하였다. 염 기서열을 이용하여 NCBI site의 Basic Local Alignment Search Tool (BLAST)에 탑재되어 있는 blastn프로그램을 이용 하여 $16 \mathrm{~S}$ ribosomal RNA sequences의 데이터베이스와 비교하 여 분리된 균을 동정하였다. 그 결과 산림토양으로부터 분리된 균주는 Bacillus subtilis strain IAM 12118 (99\%), Bacillus mojavensis strain IFO15718 (99\%), Bacillus subtilis strain 168 (99\%), Bacillus mojavensis strain ifo 15718 (100\%), Bacillus axarquiensis strain LMG 22476 (100\%), Brevibacterium halotolerans strain DSM 8802 (100\%) 등과 높은 상동성을 보 였다. 게다가 Phylogenetic 분석에 의하면 분리된 균주는 Brevibacterium halotolerans LMG 21660T (AJ620368), Bacillus mojavensis IFO 15718T (AB021191), Bacillus subtilis subsp. spizizenii NRRL B-23049T (AF074970), Bacillus sp. JMY 1 와 같은 계통에 속하였다(Fig. 1). 이러한 결과들은 분리된 박 테리아는 Bacillus 종에 속하는 것임을 강력하게 시사한다. 따 라서 본 연구에서 분리한 균주는 Bacillus sp. GJY으로 명명하 였다.

\section{CMCase와 xylanase의 zymogram 분석}

$0.4 \%$ birchwood xylan 또는 $0.4 \% \mathrm{CMC}$ 을 담고 있는 SDSPAGE 분석방법은 Bacillus sp. GJY에서 CMCase와 xylanase의 활성을 책임지고 있는 단백질을 알아보기 위하여 사용하였다. Bacillus sp. GJY을 $2 \mathrm{~mL}$ 의 $\mathrm{LB}$ 배지에 접종하여 $30^{\circ} \mathrm{C}$ 에서 12 시간 이상 배양 하여 원심분리로 회수한 조효소액과, 세포를 분 리하여 실험에 사용하였다. 전기영동을 위하여 변성시킨 단백질 은 단백질의 전개가 끝난 후 CMCase 또는 xylanase의 활성을 확인하기 위하여 단백질을 refolding 시킨 후 효소반응을 실시 하였다. 각각의 효소 반응이 끝난 $\mathrm{SDS}$ 겔은 $0.5 \%$ congo red 용액으로 염색을 실시하고, $0.5 \% \mathrm{NaCl}$ 용액으로 $\mathrm{SDS}$ 겔을 탈 색하였다. Fig. 2B에서 보는 바와 같이 CMC zymogram분석에 서 조효소액과 cell pellet에서 동일하게 약 $28 \mathrm{kDa}$ 부근에 하나 
Table 1 Physiological characteristics of Bacillus sp. GJY

\begin{tabular}{|c|c|c|c|c|}
\hline Mnemonic & Biochemical test (Substrate) & Type of Test & Wavelength & details \\
\hline BXYL & BETA-XYLOSIDASE & Enzymatic & 430 & + \\
\hline LysA & L-Lysine-ARYLAMIDASE & Enzymatic & 430 & - \\
\hline AspA & L-Aspartate ARYLAMIDASE & Enzymatic & 660 & $(-)$ \\
\hline LeuA & Leucine ARYLAMIDASE & Enzymatic & 660 & + \\
\hline PheA & Phenylalanine ARYLAMIDASE & Enzymatic & 660 & + \\
\hline ProA & L-Proline ARYLAMIDASE & Enzymatic & 660 & - \\
\hline BGAL & BETA-GALACTOSIDASE & Enzymatic & 430 & + \\
\hline PyrA & L-Pyrrolydonyl-ARYLAMIDASE & Enzymatic & 660 & + \\
\hline AGAL & ALPHA-GALACTOSIDASE & Enzymatic & 430 & + \\
\hline AlaA & Alanine ARYLAMIDASE & Enzymatic & 660 & + \\
\hline TyrA & Tyrosine ARYLAMIDASE & Enzymatic & 660 & + \\
\hline BNAG & BETA-N-ACETYL-GLUCOSAMINIDASE & Enzymatic & 430 & $(+)$ \\
\hline APPA & Ala-Phe-Pro ARYLAMIDASE & Enzymatic & 660 & $(-)$ \\
\hline CDEX & CYCLODEXTRINE & Acidification & 660 & - \\
\hline dGAL & D-GALACTOSE & Acidification & 660 & - \\
\hline GLYG & GLYCOGENE & Acidification & 660 & + \\
\hline INO & myo-INOSITOL & Acidification & 660 & $(+)$ \\
\hline MdG & METHYL-A-D-GLUCOPYRANOSIDE & Acidification & 660 & + \\
\hline ELLM & ELLMAN & Enzymatic & 430 & + \\
\hline $\operatorname{MdX}$ & METHYL-D-XYLOSIDE & Acidification & 660 & - \\
\hline AMAN & ALPHA-MANNOSIDASE & Enzymatic & 430 & - \\
\hline MTE & MALTOTRIOSE & Acidification & 660 & + \\
\hline GlyA & Glycine ARYLAMIDASE & Enzymatic & 430 & + \\
\hline dMAN & D-MANNITOL & Acidification & 660 & + \\
\hline dMNE & D-MANNOSE & Acidification & 660 & - \\
\hline dMLZ & D-MELEZITOSE & Acidification & 660 & - \\
\hline NAG & N-ACETYL-D-GLUCOSAMINE & Acidification & 660 & - \\
\hline PLE & PALATINOSE & Acidification & 660 & + \\
\hline IRHA & L-RHAMNOSE & Acidification & 660 & - \\
\hline BGLU & BETA-GLUCOSIDASE & Enzymatic & 430 & + \\
\hline BMAN & BETA-MANNOSIDASE & Enzymatic & 430 & + \\
\hline PHC & PHOSPHORYL CHOLINE & Enzymatic & 430 & - \\
\hline PVATE & PYRUVATE & Alkalinisation & 660 & + \\
\hline AGLU & ALPHA-GLUCOSIDASE & Enzymatic & 430 & + \\
\hline dTAG & D-TAGATOSE & Acidification & 660 & - \\
\hline dTRE & D-TREHALOSE & Acidification & 660 & + \\
\hline INU & INULIN & Acidification & 660 & + \\
\hline dGLU & D-GLUCOSE & Acidification & 660 & + \\
\hline $\mathrm{dRIB}$ & D-RIBOSE & Acidification & 660 & + \\
\hline $\mathrm{PSCNa}$ & PUTRESCINE assimilation & Assimilation & 660 & - \\
\hline $\mathrm{NaCl} 6,5 \%$ & Growth in $6,5 \% \mathrm{NaCl}$ & Inhibition & 660 & + \\
\hline KAN & KANAMYCIN RESISTANCE & Inhibition & 660 & - \\
\hline OLD & OLEANDOMYCIN RESISTANCE & Inhibition & 660 & - \\
\hline ESC & ESCULIN hydrolyse & Precipitation & 660 & + \\
\hline TTZ & TETRAZOLIM RED & Precipitation & 660 & + \\
\hline POLYB_R & PLOMIXIN_B RESISTANCE & Inhibition & 660 & - \\
\hline
\end{tabular}

씩의 밴드가 생성되었다. $16 \mathrm{~S}$ rRNA 분석에서 Bacillus sp. GJY와 Bacillus subtilis strain T30 (CP011051.1)의 게놈은 99 $\%$ 이상의 높은 상동성을 보였다. 게놈 분석에 의하면 Bacillus subtilis strain $\mathrm{T} 30$ 은 총 2개의 glucanase 유전자(AJW87252.1, AJW87391.1)를 가지고 있었다. AJW87252.1 유전자는 $1500 \mathrm{bp}$
의 open reading frame (ORF)를 가지며, 약 $55.5 \mathrm{kDa}$ 의 단백 질을 코딩하고 있는 것으로 나타났다. 그에 반하여 AJW87391.1 는 약 $732 \mathrm{bp}$ 의 $\mathrm{ORF}$ 를 가지며 약 $27.4 \mathrm{kDa}$ 의 단백질을 코딩하 고 있었다. Signal IP프로그램(http://www.cbs.dtu.dk/services/ SignalP/)을 이용한 signal peptide 분석에서 두 유전자는 모두 


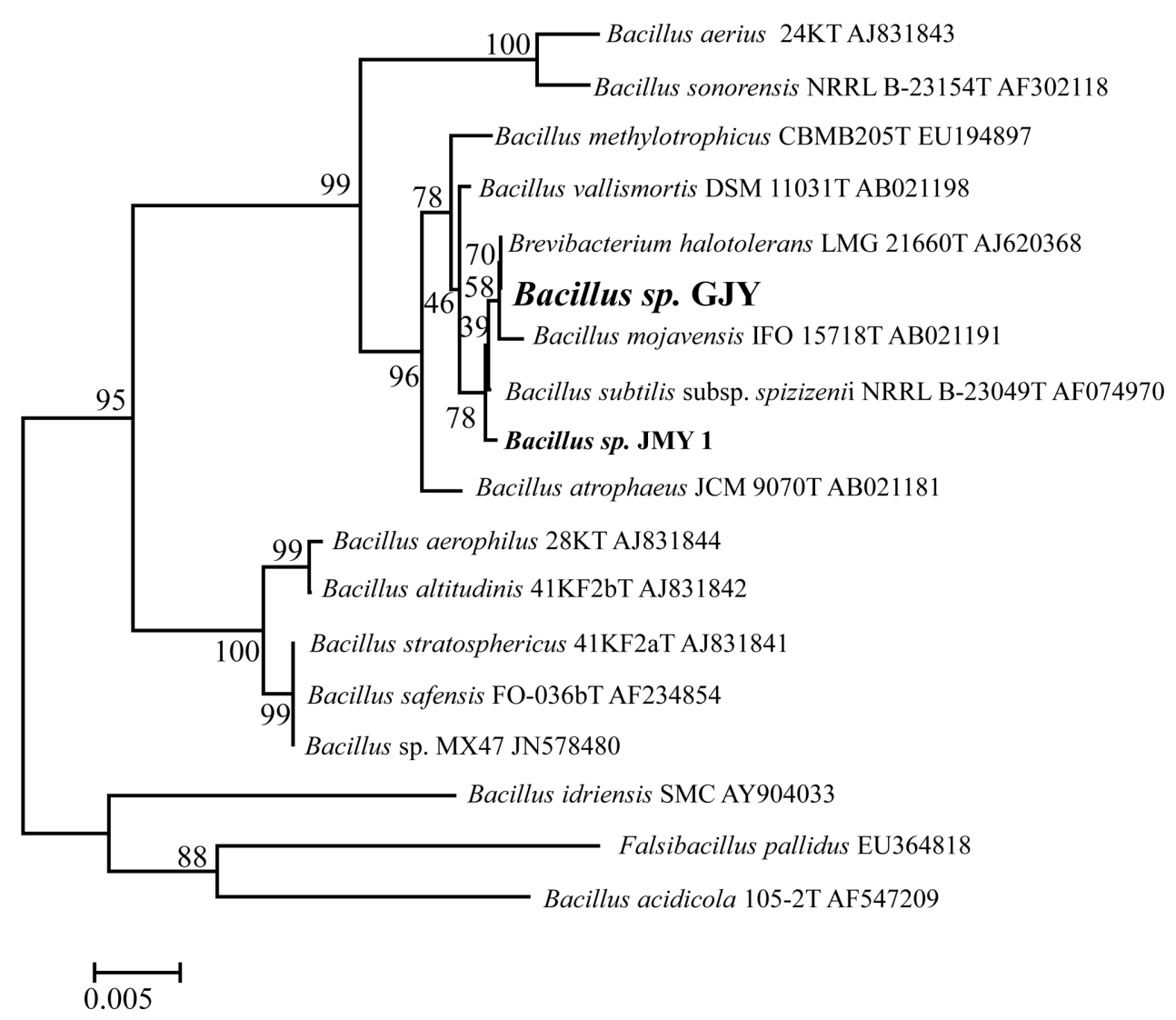

Fig. 1 A neighbor-joining phylogenetic tree based on the 16S rRNA gene sequence of Bacillus sp. GJY with 16S rRNA gene sequences from other bacteria. The distance matrix was determined using the Kimura two-parameter model. The bootstrap values were calculated with 1000 replicates regenerated with random method. Scale bar 0.05 indicates the substitutions per 100 nucleotides
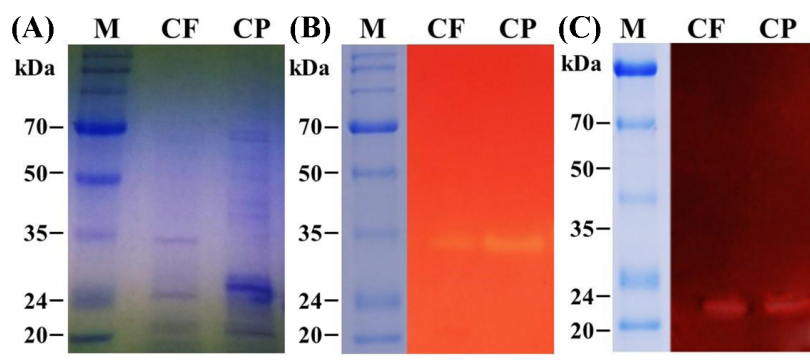

Fig. 2 Detection of CMCase and xylanase activities from Bacillus sp. GJY by SDS-PAGE containing $0.4 \% \mathrm{CMC}$ and birchwood xylan, respectively. SDS-PAGE gel stained with coomassie blue (A). CMC zymogram (B), Xylan zymogram (C). M, molecular marker weight standard; $\mathrm{CF}$ culture filtrate, $\mathrm{CP}$ cell pellets

세포외부로 방출되는데 필요한 peptide를 가지고 있었다. Zymogram의 결과와 비교해 보면 AJW87391.1가 CMCase의 활성을 책임지고 있을 가능성이 높아 보인다. AJW87391.1가 Bacillus sp. GJY에서 CMCase의 활성에 책임지고 있는지에 대 하여 알아보기 위하여 유전자의 클로닝, 재조합 단백질을 생산 등의 향후의 연구가 필요할 것으로 보인다. Xylanase의 zymogram분석에서 조효소액과 cell pellet에서 동일하게 약 $20 \mathrm{kDa}$ 의 부근에 각각 밴드 하나씩이 나타났다. Bacillus subtilis strain T30 (CP011051.1)의 게놈의 분석에서 하나의 $\beta 1,4$-betaxylanase (AJW87205.1) homologue 유전자가 존재하는 것으로 나타났다. AJW87205.1는 $699 \mathrm{bp}$ 의 ORF와 $25.7 \mathrm{kDa}$ 의 단백질 을 코딩하고 있었다. AJW87205.1유전자가 Bacillus sp. GJY에 서 Xylanase의 활성을 책임지고 있을 가능성이 높아 보이지만, 향 후 유전자 클로닝과 재조합단백질 생산에 대한 연구가 필요 할 것으로 보인다.

\section{Bacillus sp. GJY의 생장특성}

Bacillus sp. GJY의 적정생장 온도를 조사하기 위하여 20, 25, $30,37,45^{\circ} \mathrm{C}$ 에서 48 시간 동안 정치배양을 실시하였다. Bacillus sp. GJY는 모든 온도에서 생장이 가능하였다. $37^{\circ} \mathrm{C}$ 에서 생장 이 가장 왕성하였지만, $30^{\circ} \mathrm{C}$ 에서도 $37^{\circ} \mathrm{C}$ 와 비교할 만큼 생장 이 좋았다. $25,45^{\circ} \mathrm{C}$ 에서는 $37^{\circ} \mathrm{C}$ 에 비해서 약 $60 \%$ 정도의 생장을 보였지만, $20^{\circ} \mathrm{C}$ 에서는 생장이 둔화되었다. 위와 같은 결 과로 보아 Bacillus sp. GJY는 중온성 균에 속하는 것을 알 수 있었다.

Bacillus sp. GJY의 배양기간 동안 생장과 효소활성과의 관 계를 알아보기 위하여 $37^{\circ} \mathrm{C}$ 가 유지되는 배양기에서 배양 시간 $(0,4,8,12,24,48$ 시간) 별로 $\mathrm{CMCase}$ 와 xylanase의 효소활 성을 측정하였다. Bacillus sp. GJY의 생장과 함께 CMCase와 xylanase의 효소 활성도 증가하였다. Bacillus sp. GJY의 생장은 


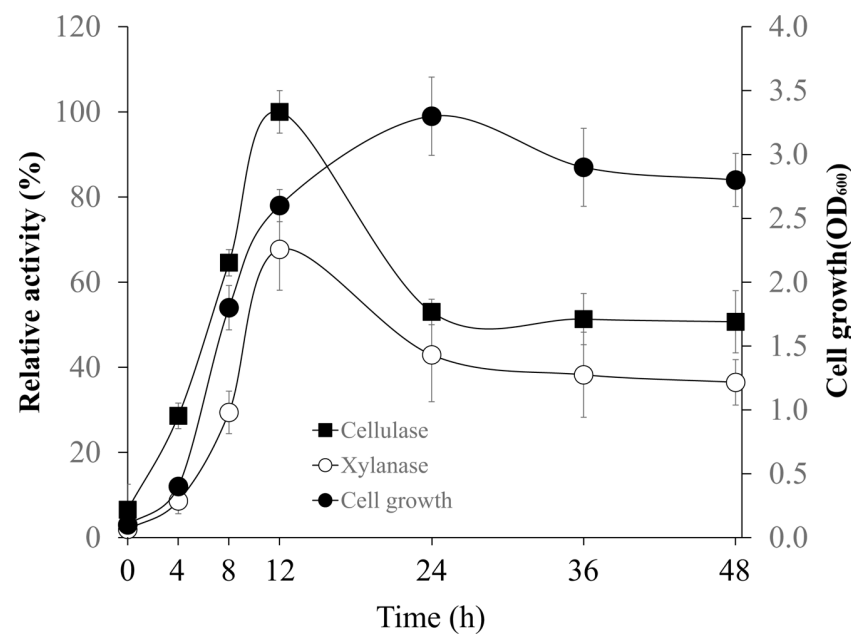

Fig. 3 Cell growth and enzymatic activities of xylanase and CMCase produced by Bacillus sp. GJY according to culture time. Bacillus sp. GJY was cultured at $37{ }^{\circ} \mathrm{C}$ with $200 \mathrm{rpm}$ shaking. The enzymatic activities were determined in $50 \mathrm{mM}$ sodium acetate buffer containing $1 \%(\mathrm{w} / \mathrm{v})$ $\mathrm{CMC}\left(\mathrm{pH} \mathrm{5.0)}\right.$ and xylan (pH 4.0) at $50{ }^{\circ} \mathrm{C}$. All results are presented by mean $\pm \mathrm{SD}(n=3)$

배양 후 24시간에 세포밀도가 최고에 도달하였으며 24시간 이 후 박테리아의 생장량이 조금씩 감소 하였다(Fig. 3). 이러한 결 과는 박테리아의 생장에 공급된 에너지원이 24시간 정도 배양 하면 영양분의 대부분이 고갈되기 때문에 더 이상 박테리아 세 포의 밀도증가가 일어나지 않는 것으로 보인다. CMCase의 효 소 활성은 박테리아 배양 후 4시간부터 급격하게 증가되다가 12 시간에 최대의 효소활성을 보였으며 그이 후 약 $50 \%$ 까지 활 성이 줄어들었다(Fig. 3). Xylanase의 효소활성은 CMCase의 효 소활성에 대한 상대 활성 값으로 나타내었을 때 약 $70 \%$ 정도 의 활성을 가지는 것으로 나타났다. Xylanase역시 박테리아 세 포의 생장에 따라 활성이 점점 증가하였다. 배양 후 12 시간에 가장 높은 xylanase활성을 보였으며 그 시간 이후 점차 활성이 감소되는 경향을 보였다. 12시간 이후 CMCase와 xylanase의 두 효소활성이 급격하게 감소하는 경향을 보였는데 이러한 이 유는 배지 내에 사용 가능한 탄소원의 고갈로 인하여 $\mathrm{CMC}$ 와 xylanan 분해 단백질의 생합성이 줄어든 원인으로 보인다.

\section{CMCase와 Xylanase의 적정 온도 및 $\mathbf{p H}$}

Bacillus sp. GJY 유래 CMCase와 Xylanase의 효소활성에 영향 을 미치는 $\mathrm{pH}$ 및 온도의 영향을 Fig. 9에 나타내었다. 분리된 균주의 CMCase와 xylanase의 적정 $\mathrm{pH}$ 는 $40{ }^{\circ} \mathrm{C}$ 에서 $\mathrm{pH} 3.0-9.0$ 까지 7개의 서로 다른 $\mathrm{pH}$ 조건에서 각각 효소활성을 측정하였 다. $\mathrm{CMCase}$ 의 경우 $\mathrm{pH} 5.0$ 에서 가장 높은 활성을 보였다. 다 음으로 $\mathrm{pH}$ 6.0으로 $\mathrm{pH} 5.0$ 의 약 $80 \%$ 의 효소활성을 보였다. $\mathrm{pH}$ 8.0과 9.0에서는 대부분의 CMCase 활성을 잃어버리는 것 을 보였다(Fig. 4). Xylanase의 경우 $\mathrm{pH} 4.0$ 에서 가장 높은 효 소활성을 보였지만, $\mathrm{pH} 5.0$ 의 경우도 $\mathrm{pH} 4.0$ 에서의 활성과 비 교해서 약 $95 \%$ 정도의 활성을 유지하고 있었다. CMCase와 달 리 xylanase는 $\mathrm{pH}$ 8.0과 $\mathrm{pH}$ 9.0과 같은 높은 산도에서도 30 $\%$ 이상의 효소 활성을 유지하고 있는 것으로 나타났다. 이상의

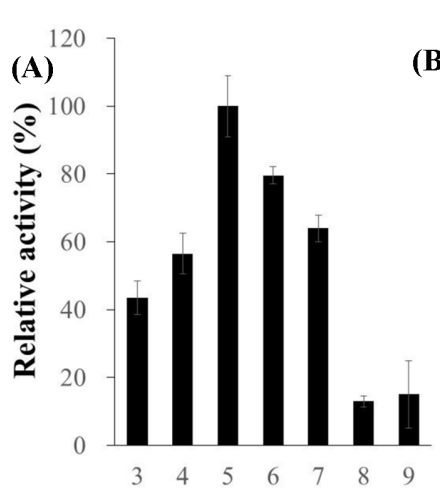

(B)
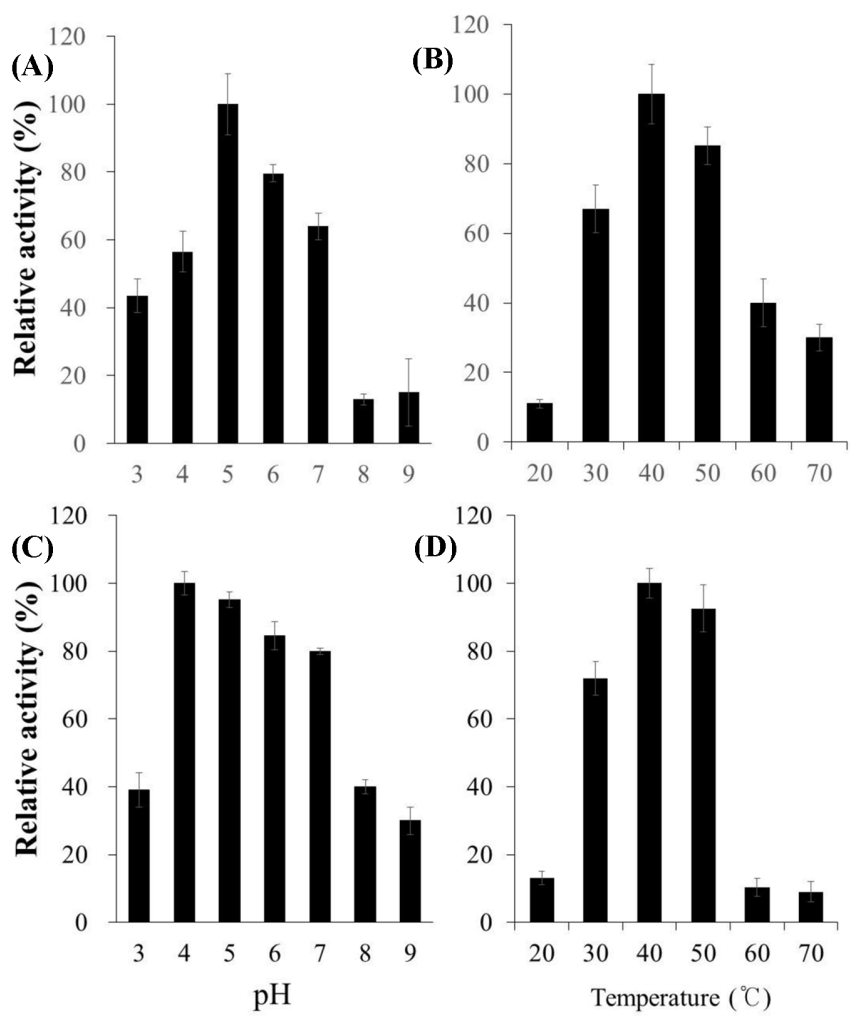

Fig. 4 Effect of $\mathrm{pH}$ and temperature on the relative activity of CMCase (A and $\mathrm{B}$ ) and xylanase ( $\mathrm{C}$ and $\mathrm{D})$. The effect of $\mathrm{pH}$ and temperature were evaluated with $50 \mathrm{mM}$ sodium acetate buffer and containing $1 \%(\mathrm{w} /$ v) CMC and birchwood xylan, respectively. All data are represented as mean $\pm \mathrm{SD}(n=3)$

결과를 살펴보면 Bacillus sp. GJY의 경우 $\mathrm{pH}$ 4.0-6.0 사이의 약산성과 중성에서 $\mathrm{CMCase}$ 와 xylanase의 최대 효소활성을 나 타내었다. 이러한 결과는 이전에 보고되었던 Bacillus속 유래의 CMCase와 xylanase의 연구결과와 유사한 경향을 보였지만 (Kim 등, 2012; Lee 등, 2016), xylanase의 경우 산에 대해 더 높은 내성을 가지는 것으로 나타났다.

Bacillus sp. GJY 유래 CMCase와 xylanase의 활성에 영향을 미치는 온도의 영항을 알아보기 위하여 $20-70{ }^{\circ} \mathrm{C}$ 사이의 6 가지 의 서로 다른 온도에서 각각의 효소활성을 측정하였다. 그 결 과 $\mathrm{CMCase}$ 와 xylanase는 $40^{\circ} \mathrm{C}$ 에서 가장 높은 효소활성을 보 였으며, 다음으로 $50^{\circ} \mathrm{C}$ 로 $40^{\circ} \mathrm{C}$ 의 효소활성에 비교해서 약 85 $\%$ 이상의 효소 활성을 가지는 것으로 나타났다(Fig. 4). $30{ }^{\circ} \mathrm{C}$ 의 반응온도에서 $\mathrm{CMCase}$ 와 xylanase의 효소 활성은 최대 활성 온 도에 비해서 약 $70 \%$ 이상을 가지는 것으로 나타났다. 하지만, $60{ }^{\circ} \mathrm{C}$ 이상의 반응온도에서는 CMCase와 xylanase의 효소활성 이 급격하게 감소하는 경향을 보였다. 이상의 결과를 요약하면 Bacillus sp. GJY 유래 CMCase와 xylanase활성은 $40-50{ }^{\circ} \mathrm{C}$ 범 위에서 최적 온도를 나타내는 특성을 가지고 있는 것을 알 수 있다. 따라서 본 연구에서 분리한 박테리아는 이전에 Bacillus 속유래 CMCase와 xylanase와 유사한 경향의 최적 반응온도를 가지는 것으로 나타났다(Qu와 Shao 2011; Kim 등, 2012; Lee 등, 2016). 

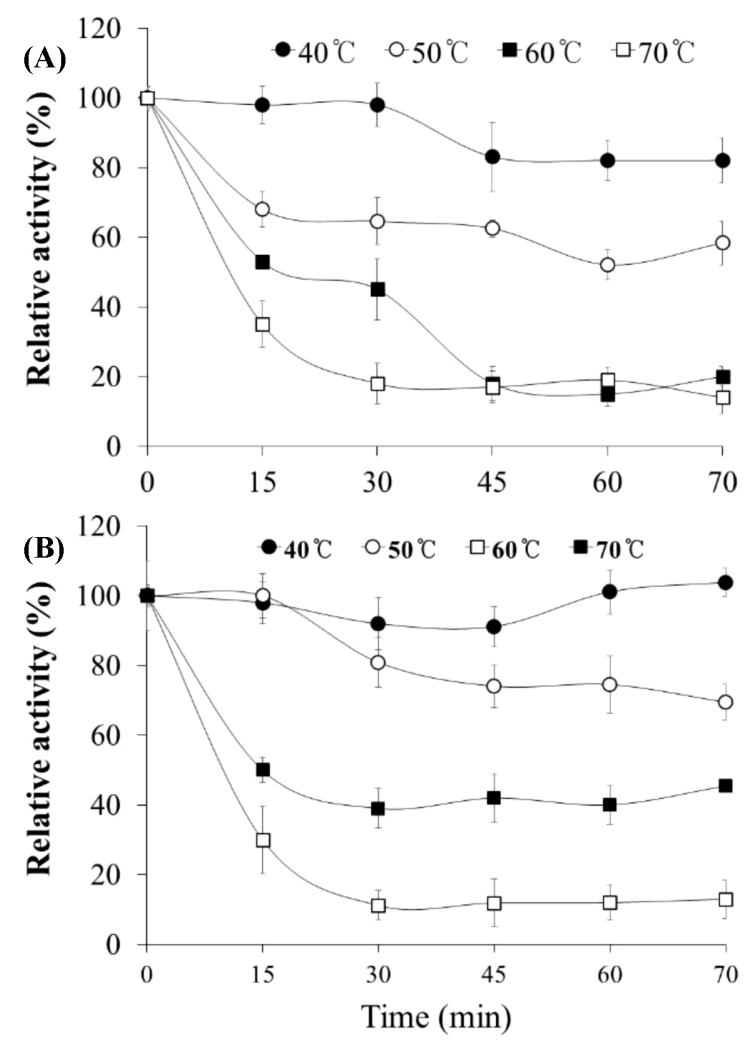

Fig. 5 Thermal stability of CMCase (A) and xylanase (B) from Bacillus sp. GJY. The thermal stabilities on the both enzymes were evaluated in $50 \mathrm{mM}$ sodium acetate buffer containing $1 \%(\mathrm{w} / \mathrm{v}) \mathrm{CMC}(\mathrm{pH} 5.0)$ and xylan ( $\mathrm{pH} 4.0)$ at $40,50,60$, and $70{ }^{\circ} \mathrm{C}$. All results are presented by mean $\pm \mathrm{SD}(n=3)$

\section{CMCase와 Xylanase의 온도 안정성}

Bacillus sp. GJY 유래 CMCase와 Xylanase의 열 안정성에 대 한 결과를 Fig 10에 나타내었다. 열 안정성 평가는 기질 없이 $15,30,45,60,70$ 분까지 배양한 후 남아 있는 효소의 활성을 측정하였다. CMCase의 경우 $40{ }^{\circ} \mathrm{C}$ 에서 30 분까지 효소활성에 거의 영향을 미치지 않았고 45-70분간 배양 한 후 남아 있는 효소 활성도 $80 \%$ 이상을 유지하고 있는 것을 보였다. 하지만, $\mathrm{CMCase}$ 의 활성은 $60{ }^{\circ} \mathrm{C}$ 와 $70^{\circ} \mathrm{C}$ 에서는 급격하게 감소하는 경 향을 보였다(Fig 5). Xylanase는 $40{ }^{\circ} \mathrm{C}$ 와 $50{ }^{\circ} \mathrm{C}$ 에서 굉장히 안 정적이었다(Fig 5). $40{ }^{\circ} \mathrm{C}$ 의 경우에는 거의 효소가 안정하게 유 지되는 것을 보였다. $50{ }^{\circ} \mathrm{C}$ 의 경우 30 분간 효소를 배양했을 때 약 $20 \%$ 정도의 활성이 줄어드는 경향을 보였지만, 70 분간 배 양 했을 때도 $80 \%$ 이상의 xylanase활성을 유지하고 있는 것을 보였다. $60{ }^{\circ} \mathrm{C}$ 의 경우 에서 배양한 후 70 분까지 약 $40 \%$ 의 활 성을 유지하고 있는 결과를 보인 반면 $70{ }^{\circ} \mathrm{C}$ 에서 배양했을 경 우에는 대부분의 효소활성을 잃어버리는 경향을 보였다. 결론적 으로 CMCase 또는 xylanase는 $40-50{ }^{\circ} \mathrm{C}$ 비교적 안정하였지만, $60-70{ }^{\circ} \mathrm{C}$ 에서는 굉장히 불안정한 결과를 보였다. 이러한 결과는 Bacillus sp. GJY이 생산하는 CMCase 또는 xylanase는 중온성 효소(mesophilic enzyme)임을 강력하게 시사한다.

\section{초 록}

토양 내에 존재하는 미생물은 다양한 종류의 다당류 분해 효소 들을 생산함으로써 토양의 비옥도 증진뿐만 아니라 토양내의 생 태계를 건전하게 유지하게 위해 중요한 역할을 한다. 본 연구 는 경남과학기술대학교에 위치한 쥬라기숲에서 $0.4 \%$ carboxymethyl cellulose와 $0.01 \%$ trypan blue가 첨가된 $\mathrm{LB}$ agar plate를 이용하여 CMCase와 xylanase를 생산하는 박테리 아를 분리하였다. $16 \mathrm{~S}$ rRNA 유전자 염기서열 분석과 API kit 분석을 바탕으로 분리된 박테리아는 Bacillus 종에 속하는 것으 로 동정되었으며, Bacillus sp. GJY으로 명명하였다. Bacillus sp. GJY에서 CMCase와 xylanase의 활성을 책임지고 있는 단백 질을 알아보기 위하여 Zymogram 분석을 실시하였다. 그 결과 CMCase의 경우 약 $28 \mathrm{kDa}$ 크기에 xylanase의 경우 약 $25 \mathrm{kDa}$ 크기에 활성밴드가 하나씩 존재하였다.

Bacillus sp. GJY의 최적 생장온도는 $37^{\circ} \mathrm{C}$ 이었으며, CMCase 와 xylanase의 활성은 배양 후 12 시간에 최고에 달하였다. $\mathrm{CMCase}$ 의 경우 $\mathrm{pH} 5.0$, 온도 $40{ }^{\circ} \mathrm{C}$ 에서 최적의 활성을 보인 반면, xylanase는 $\mathrm{pH} 4.0,40^{\circ} \mathrm{C}$ 에서 최적의 활성을 보였다. $\mathrm{CMCase}$ 와 xylanase 모두 $40,50{ }^{\circ} \mathrm{C}$ 에서는 열 안정성을 보였지 만, $60{ }^{\circ} \mathrm{C}$ 이상에서는 두 효소의 열 안정성이 급격하게 감소하 는 경향을 보였다.

Keywords 목질바오이매스·바실러스·자이모그램·자일라나아제

감사의 글 이 논문은 경남과학기술대학교 2015 년도 대학회계 연구비에 의 하여 연구되었음.

\section{References}

Ayres E, Steltzer H, Berg S, Wall DH (2009) Soil biota accelerate decomposition in high-elevaion forests by specializing in the breakdown of litter produced by the plant species above them. J Ecol 97: 901-912

Demain AL, Newcom M, Wu JHD (2005) Cellulase, clostridia, and ethanol. Microbiol Mol Bio Rev 69: 124-154

Khandeparker R, Verma P, Deobagkar D (2011) A novel halotolerant xylanase from marine isolate Bacillus subtilis cho40: gene cloning and sequencing. N Biotechnol. 28: 814-821

Kim YK, Lee SC, Cho YY, Oh HJ (2012) Isolation of cellulolytic Bacillus subtilis strains from agricultural environments. ISRN Microbiol Article ID 650563 1-9

Kuhad RC, Gupta R, Singh A (2011) Microbial cellulases and their industrial applications. Enzyme Res ID 280696 1-10

Kuhad RC, Manchanda M, Singh A (1999) Hydrolytic potential of extracellular enzymes from a mutant strain of Fusarium oxysporum. Bioprocess Engineering 20(2): 133-135

Kumar R, Singh S, Singh OV (2008) Bioconversion of lignocellulosic biomass: biochemical and molecular perspectives. J Ind Microbiol Bioechnol. 35: 377-391

Lee CK, Jang MY, Park HR, Choo GC, Cho HS, Park SB, Oh KC, An JB, Kim BG (2016) Cloning and characterization of xylanase in cellulolytic Bacillus sp. strain JMY1 isolated from forest soil. App Bil Chem 59(3): 415-423 
Min SY, Kim BG, Lee C, Hur HG, Ahn JH (2002) Purification, characterization, and cDNA cloning of xylanase from Fungus Trichoderma strain SY. J. Microbiol biotechnol 12: 890-894

Potter CS, Klooster SA (1997) Global model estimates of carbon and nitrogen storage in litter and soil pools: Response to change in vegetation quality and biomass allocation. Tellus 49: 1-17

Qu W, Shao W (2011) Cloning, expression and characterization of glycoside hydrolase family 11 endoxylanase from Bacillus pumilus ARA Biotechnol Lett 33: 1407-1416

Schallmey M, Singh A, Ward OP (2004) Developments in the use of Bacillus species for industrial production. Can J Microbiol 50: 1-17

Sukumaran RK, Singhania RR, Pandey A (2005) Microbial cellulasesproduction, applications and challenges. Journal of Scientific and Industrial Research. 6(11): 832-844

Sun Y, Cheng J (2002) Hydrolysis of lignocellulosic materials for ethanol production: a review. Bioresource Technology 83(1): 1-11

Tamura K, Stecher G, Peterson D, Filipski A, Kumar S (2013) MEGA6: Molecular Evolutionary Genetics Analysis version 6.0. Mol Biol Evol 30: $2725-2729$

Tjalsma H, Antelmann H, Jongbloed JD, Braun PG, Darmon E, Dorenbos R, Dubois JY, Westers H, Zanen G, Quax WJ, Kuipers OP, Bron S, Hecker
M, van Dijl JM (2004) Proteomics of protein secretion by Bacillus subtilis: separating the secrets of the secreome. Microbiol Mol Biol Rev 68: 207-233

Urbanová M, Šnajdr J, Baldrian P (2015) Composition of fungal and bacterial communities in forest litter and soil is largely determined by dominant trees. Soil Biol Biochem 84: 53-64

Waldrop MP, Zak DR, Sinsabaugh RL, Gallo M. Lauber C (2004) Nitrogen deposition modifies soil carbon storage through changes in microbial enzymatic activity. Eco Appl 14: 1172-1177

Whistler RL, Richards EL (1970) Hemicelluloses. In: Pigman W, Horton D, editors. The carbohydrates. New York: Academic press. 173: 697-703

Wilson DB (2011) Microbial diversity of cellulose hydrolysis. Curr Opin Microbiol 14: 1-5

Yang JK, Zhang JJ, Yu HY, Cheng JW, Miao LH (2014) Community composition and cellulase activity of cellulolytic bacteria from forest soils planted broad-leaved deciduous and evergreen trees. Appl Microbiol Biotechnol 98: 1449-1458

Zang XZ, Zhang YHP (2011) Simple, fast and high-efficiency transformation system for directed evolution of cellulase in Bacillus subtilis. Microbial Biotechnology 4: 98-105 